\title{
Intra and Inter-Individual Differences in Social Intelligence of Portuguese Students ${ }^{1}$
}

\author{
Joana Carneiro Pinto ${ }^{2}$ \\ Universidade Católica Portuguesa, \\ Lisboa, Portugal \\ Neide Gaspar \\ Instituto Superior de Línguas e \\ Administração, Leiria, Portugal
}

\author{
Liliana Faria \\ Universidade Europeia, Lisboa, \\ Portugal \\ Maria do Céu Taveira \\ Universidade do Minho, Braga, \\ Portugal
}

\begin{abstract}
Social intelligence is a favorable condition for career decision-making and development. The social intelligence indices of Portuguese students in school years prior to a career transition are characterized and intra and interindividual differences are analyzed. Participants were 1095 students $(552,50.4 \%$ women) with a mean age of 14.78 years $(S D=1.86)$, in the 8 th $(542$, $49.5 \%), 10$ th $(295,26.9 \%)$ and 11 th $(258,23.6 \%)$ grades. The Cognitive Test of Social Intelligence (PCIS) was administered at two moments, six months apart. Results indicate that the 8th grade obtained higher average scores in Problem Solving, Motivation and Self-confidence (time 1), while the 10th grade obtained better results in Problem Solving, Motivation and Familiarity (time 2). Between the assessment moments, all school years register an increase in Problem Solving and Self-confidence in social situations. These results constitute favorable psychological conditions for the promotion of ethical questioning in career guidance interventions.
\end{abstract}

Keywords: intelligence, ethics, vocational guidance

\section{Diferenças Intra e Inter Individuais na Inteligência Social de Estudantes Portugueses}

\begin{abstract}
Resumo: A inteligência social constitui uma condição favorável à tomada de decisão e ao desenvolvimento vocacional. Este trabalho visa caracterizar os níveis de inteligência social, e analisar as diferenças intra e interindividuais, em alunos portugueses em anos de pré-transição vocacional. Participaram 1095 alunos (552, 50\% mulheres), com uma média de idades de 14,78 anos $(D P=1,86)$, do $8^{\circ}, 10^{\circ}$, e $11^{\circ}$ níveis escolares. Administrou-se a Prova Cognitiva de Inteligência Social (PCIS), em dois momentos (T1 e T2), com seis meses de intervalo. Os resultados indicam que o $8^{\circ}$ ano obteve resultados médios superiores, nos índices de Resolução de Problemas, Motivação e Autoconfiança (T1), enquanto o $10^{\circ}$ ano obteve resultados superiores, em Resolução de Problemas, Motivação e Familiaridade (T2). Entre momentos de avaliação, registra-se, para todos os níveis escolares, um aumento em Resolução de Problemas e Autoconfiança em situações sociais. Estes resultados constituem condições psicológicas favoráveis à promoção do questionamento ético nas intervenções de orientação vocacional.
\end{abstract}

Palavras-chave: inteligência, ética, orientação vocacional

\section{Diferencias Intra e Inter Individuales en Inteligencia Social de Estudiantes Portugueses}

\begin{abstract}
Resumen: La inteligencia social es una condición favorable para la toma de decisiones y el desarrollo de la carrera. Se caracterizan los niveles de inteligencia social y sus diferencias intra e interindividuales en estudiantes portugueses en transición pre-profesional. Participaron 1095 estudiantes $\left(552,50.4 \%\right.$ mujeres) con una edad media de $14.78(D E=1.86)$, del $8^{\circ}(542$, $49,5 \%), 10^{\circ}(295,26.9 \%)$ y $11^{\circ}(258,23.6 \%)$ años escolares. Se administró la Prueba Cognitiva de Inteligencia Social (PCIS) en dos ocasiones, con seis meses de diferencia. Los resultados indican que los estudiantes del $8^{\circ}$ grado obtuvieron puntajes medios más altos en la Resolución de Problemas, Motivación y Confianza (T1), mientras que los del $10^{\circ}$ grado obtuvieron mejores resultados en la Resolución de Problemas, Motivación y Familiaridad (T2). Entre momentos de evaluación se registra, para todos los años, un aumento en la Resolución de Problemas y Confianza en situaciones sociales. Estos resultados constituyen condiciones psicológicas favorables a la promoción del cuestionamiento ético en las intervenciones de orientación profesional.
\end{abstract}

Palabras clave: inteligencia, ética, orientación vocacional

\footnotetext{
${ }^{1}$ Paper deriving from the third author's master's thesis under the primary and secondary authors' orientation, defended in the Master's Program at the Instituto Superior de Línguas e Administração de Leiria - Portugal in 2013. Support: Project coordinated by the fourth author and co-funded by the Foundation for Science and Technology and the Compete Program PTDC/CPE-CED/098896/2008.

2 Correspondence address:

Joana Carneiro Pinto. Faculdade de Ciências Humanas, Universidade Católica Portuguesa. Palma de Cima, 1649-023. Lisboa, Portugal. E-mail: joanacarneiropinto@fch.lisboa.ucp.pt
}

No consensus definition of social intelligence exists, especially because this construct is located very close to concepts like skills, abilities and social skills. In addition, other constructs like emotional intelligence (Cherniss, 2010; Lacanlale, 2013; Por, Barribal, Fitzpatrick, \& Robert, 2011) or interpersonal intelligence (Juchniewicz, 2010) partially overlap. 
Originally developed in the early twentieth century by Edward Thorndike, the construct of social intelligence began to indicate a person's ability to understand and act with wisdom and effectiveness in interpersonal tasks (Thorndike, 1920). In this definition, the dominant notion of intelligence, coupled with a high intelligence quotient, loses relevance, highlighting the person's ability to manage efficient social interactions and human relations. Between 1920 and 1980, the study of this construct was troubled, characterized by a series of setbacks and advances in its understanding. While authors like Wechsler (1958) define it as "general intelligence applied to social situations" Goleman (2006, p.131), Guilford (1967), Moss and Hunt (1927) and Vernon (1933) adopt a more positive attitude, stating that social intelligence is a different dimension of other forms of intelligence, associated with social awareness, interpersonal interactions, and the recognition of the needs, feelings, thoughts and behaviors in themselves and in others. Recently, Brislin, Worthley and Macnab (2006) defined social intelligence as the interaction skills with social groups, in particular knowledge of social rules and social life, analysis of verbal and non-verbal language, flexibility and sensitivity to different social situations of some complexity.

Despite the difficulty in defining this theoretical construct, there is unanimity among scholars that social intelligence refers to cognitive-analytical and behavioral components (Bjorkqvist, 2007) and is an essential condition to ensure survival and effective adaptation to the world.

In this sense, Candeias $(2003,2007)$ adopts an integrative approach to the concept, referring to social intelligence as the ability to explore, analyze and interpret information, to solve problems, achieve goals and make intentional, planned, and successful decisions about interpersonal situations. This definition was adopted in this study and has its roots in a cognitive and contextual approach to operationalize social intelligence in the person-environment interaction, according to three components: (a) the process of problem solving, (b) knowledge and (c) the attitudes. The problem-solving process includes decoding and understanding of information about the social problem and the design of a settlement plan, its implementation and evaluation (Pretz, Naples, \& Sternberg, 2003). The knowledge reflects the expressed and latent content of the interpersonal situation, and also the important traits (e.g. behaviors, emotions) in decoding and inferring in information about the situation. Finally, attitudes include self-perception about levels of motivation, familiarity and trust in the social situation (Candeias, 2007).

The literature shows that people with high levels of social intelligence are typically friendly, supportive, thoughtful, more adaptable and efficient in dealing with various social issues and successful in society (Birknerová, Frankovský, \& Zbihlejová, 2013; Joseph \& Lakshmi, 2010). They also have more confidence in social situations, demonstrate a genuine concern for their companions and express their emotions and feelings with clarity and assertiveness (Zirkel, 2000). In addition, high levels of social intelligence seem to permit the solution of interpersonal problems, mediation and reduction of conflicts, leading communication processes and thus avoiding maladaptive pathways (Crowne, 2009; Fletcher, Leadbetter, Curran, \& O'Sullivan, 2009; Goleman, 2006).

Social intelligence has been also linked to positive outcomes, such as, for example, self-confidence, assertiveness (Bartone, Eid, Johnsen, Laberg, \& Snook, 2009; Birknerová et al., 2013), management of emotions (Zirkel, 2000), leadership (Boyatzis \& Ratti, 2009; Goleman, Boyatzis, \& McKee, 2013) and job satisfaction (Aminpoor, 2013; Koydemir, Simsek, Schutz \& Tipandjan, 2013; Yahyazadeh-Jeloudar \& Lotfi-Goodarzi, 2012).

In the academic context, studies of social intelligence are scarce but make important contributions (Goleman, 2006; Nagra, 2014; Saxena \& Jain, 2013). Meijs, Cillessen, Scholte, Segers and Spijkerman (2010), for example, comparing the effect of social and cognitive intelligence (academic performance) in perceived popularity (social dominance) and sociometric popularity (social acceptance) with Northwest European teenagers $(N=512)$ of both sexes, between 14-15 years of age, studying in regular and vocational schools. They found that perceived popularity was significantly related with social intelligence, but not with academic performance in both teaching contexts. They also found that sociometric popularity depended on a social intelligence interaction effect with academic performance in regular students and the effect of each of the independent factors in vocational students.

Soares, Francischetto, Peçanha, Miranda and Dutra (2013) studied the influence of intelligence and social skills in the academic adaptation to university of 393 male and female Brazilian students and found that only the social skills reported a significant positive correlation with the academic adjustment. Other studies have shown that students with high cognitive abilities, compared to their peers with average performance, have better results in social intelligence measures, but not necessarily in social competence measures (Candeias, 2003, 2007; Lopez, 2007). In another similar study, conducted with 506 Chinese college students, Song et al. (2010) demonstrated that both global cognitive ability and social-emotional intelligence influence academic achievement. Only the social-emotional intelligence showed a significant relationship with the quality of social interactions of students in an educational context though. Carvalho (2011) evaluated the social intelligence of Portuguese students between 12 and 15 years of age, residing in Northern Portugal, and noted differences in the problemsolving index for girls; differences in the confidence index in favor of male and female older students, as well as age differences in the motivation index in favor of older students too, but only in the boys group. This author studied social intelligence as a favorable condition for ethical questioning in the field of vocational decision. That is, during their vocational decision-making processes, individuals should consider the interpersonal and societal implications of their choices and 
career construction methods. With the same purpose, Peixoto (2013) studied the social intelligence of Portuguese students of the 8th, 10th and 11th grades and found that the social problem-solving ability is higher in older students and with higher education, and implications for ethical questioning within the vocational decision were discussed.

Such results indicate that social intelligence is associated with a style of thinking, communication and positive interpersonal relationships that influence adaptation, performance, achievement and success in different contexts of life and may facilitate ethical career questioning. In addition, the results can vary depending on personal circumstances and development contexts of individuals and over time.

This study is part of this line of research and aims to contribute to further study the variability of social intelligence in adolescents. It is intended to extend the sample spectrum and goals of previous studies and collect evidence about intragroup differences in social intelligence, comparing the results obtained by each group of students from the 8th, 10th and 11th grades on a measure of social intelligence at two different moments in time. At the same time, it is intended to analyze differences between the different academic groups in social intelligence at each of the assessment moments. The analysis of the variability of the construct will permit a better understanding about the dynamics of the social intelligence construct in Portuguese students. Hence, knowing that psychological conditions exist to integrate ethical questioning in vocational guidance interventions years of vocational pre-transition (8th, 10th and 11th grades), we may prepare students for making decisions in the 9th and 12th grades.

Indeed, despite the contributions presented above, showing the relevance of the study of social intelligence, this subject still lacks extensive scientific study, particularly with regard to the consistency of change.

In this sense, this study aims to characterize the levels of social intelligence and analyze the intra-individual and inter-individual differences in Portuguese students in years of vocational pre-transition. Results will be a contribution to the effort to design different intervention offers, tailored to the specific needs of all young people. Therefore, this study is based on the following research hypotheses:

H1: A statistically significant difference is expected between the averages calculated at the two assessment moments (T1 and T2) in different grade levels, with an increase over time.

H2: A statistically significant difference is expected between the averages calculated in the different school grades, with better results for students in the 11th grade, at both assessment moments (T1 and T2).

\section{Method}

\section{Participants}

In total, 1095 adolescents participated in this study, $552(50.4 \%)$ girls and $543(49.6 \%)$ boys, with a mean age of 14.78 years $(S D=1.86 ; \operatorname{Min}=11 ; \operatorname{Max}=23)$. Of them, about
$542(49.5 \%)$ were enrolled in the 8th grade, 295 (26.9\%) in the 10th grade, and $258(23.6 \%)$ in the 11 th grade, in seven academic institutions of different geographic regions of Portugal (Braga: 127, 11.6\%; Viana do Castelo: 375, 34.3\%; Aveiro: 91, 8.3\%; Lisboa: 208, 19.9\%; Évora: 284, $25.4 \%$ ). This is a convenience, non-probabilistic sample and the choice of students from the 8th, 10th and 11th grades is related to the fact that these are academic years that anticipate important vocational decision moments in the Portuguese academic system (9th and 12th grades), and also to the interest in studying the best moment to foster students' career-related ethical questioning.

\section{Instruments}

Social intelligence was assessed by the Cognitive Test of Social Intelligence - PCIS (Candeias, 2003, 2007), a self-report instrument, with three interpersonal stimulus-situations, which illustrate real-life situations of adolescents: (a) Situation 1 - Several young people at a bus stop and an old lady who seems disoriented, being dislocated in relation to her own place; (b) Situation 2 - A young girl, standing, seems to be telling a story to a couple who is seated in a waiting room, and she is pointing to the clock; (c) Situation 3 - A professional meeting between a leader and four workers, two of them seated on a couch, with a passive attitude, while the others are standing with their arms in the air. For each stimulus-situation, 16 questions are presented. The first ten questions are formulated in an open response format and scored between 0 and 3 points, according to the answer's complexity, accuracy and generalization. The remaining six questions are formulated according to a five-point Likert scale (1- None and 5-Very much). The PCIS provides four indices for each situation: (a) Problem Resolution ( $\operatorname{Min}=0 ;$ Max $=24 ;$ Mean score $=12)$; (b) Motivation ( Min $=2 ;$ Max $=10 ;$ Mean score $=6)$; (c) Self-confidence (Min $=2 ;$ Max $=10 ;$ Mean score $=6)$; and (d) Familiarity (Min = 2; Max =10; Mean score =6). A global score can also be obtained through the sum of the scores on each index per social situation. The validation studies of PCIS (Candeias, 2007) proved its dimensionality, organized by four factors that explain $53.52 \%$ of the total variance of the items, as well as internal consistency items (.58 and .96 in the Familiarity and Problem Resolution indices, respectively).

\section{Procedure}

Data collection. This study is part of a broader research study "Career and citizenship: Personal and contextual conditions of the ethical questioning of life projects". After the authorizations by school boards, parents and students involved, the PCIS was individually administered, in the classroom, during classes, after agreement with the class teacher. Teachers were asked not to give any information 
to students before the data collection day so as to prevent them from skipping the classes. Students were assessed who were attending classes and voluntarily completed the test. The test was administered only at one moment in time, and without the possibility of students interacting with each other. It is important to state that students remained in the classroom throughout the lecture, so that the dropout rate would not increase. Researchers alerted to the importance of filling out all of the data, as completely as possible, avoiding non answers. Instructions were written in the test, but could also be clarified orally and individually upon the students' request. The average time to complete the test was about 45 minutes. The test was administered at two assessment moments, with a six-month interval: the first application (T1) and the second application (T2).

Data analysis. The collected data were inserted and treated using IBM SPSS for Windows, version 20.0. After verifying the normality trend of the mean distribution, we used the parametric tests of repeated measures. Thus, besides the descriptive statistical analysis, inferential analyses were also applied to study the differences between assessment moments and groups. In the intra-group differences analysis, t-tests were used for one sample, and t-tests for paired samples to compare the results obtained for $\mathrm{T} 1$ and $\mathrm{T} 2$ in each year. In the intergroup differences analysis, we used ANOVA to compare the three academic years at T1 and MANOVA to compare the three academic years at $\mathrm{T} 2$, using the results of $\mathrm{T} 1$ as a covariate. Results were considered statistically significant with a significance coefficient inferior to $.05(p<.05)$.

\section{Ethical Considerations}

The research was not submitted to an Ethics Committee, since that Committee is being constituted until date. Instead, permission to conduct the study was requested to the General Directorate of Education, Ministry of Education, which found that all procedures and ethical caution were taken in the research concerned as a condition of approval. Indeed, it was ensured that all staff involved in the project rigorously followed ethical guidelines associated with the collection (e.g. voluntary participation), processing and analysis of data (e.g. confidentiality of the individual results), defined in a protocol specifically developed for this purpose.

\section{Results}

The analysis of the PCIS showed that the results of the four factors evaluated in the three stimulus-situations converge with the results of their respective factor. Thus, we decided to present only the results by factor. Table 1 shows the descriptive analyses and intragroup differences in the levels of social intelligence in 8 th, 10th and 11th-grade students, respectively.

Considering the 8th grade, at the first assessment moment (T1), results above the mean score were registered for Self-confidence $(M=19.77 ; S D=3.71)$. All other indices showed results below the mean score. The differences between the participants' average scores on each index and the respective mean scores are statistically significant for all indices considered. For the second assessment moment (T2), results above the mean score were recorded for

Table 1

Social Intelligence Levels in 8th, 10th and 11th Grade Students: Descriptive Analysis and Intragroup Differences

\begin{tabular}{|c|c|c|c|c|c|c|c|c|}
\hline \multirow{2}{*}{ Indexes } & \multirow{2}{*}{ Mean score } & \multicolumn{2}{|c|}{$\mathrm{T} 1$} & \multirow{2}{*}{$\begin{array}{c}\text { T-test for } \\
\text { one sample }\end{array}$} & \multicolumn{2}{|c|}{$\mathrm{T} 2$} & \multirow{2}{*}{$\begin{array}{l}\text { T-test for } \\
\text { one sample }\end{array}$} & \multirow{2}{*}{$\begin{array}{l}\text { T-test for paired } \\
\text { samples }\end{array}$} \\
\hline & & $M(S D)$ & Min-Max & & $M(S D)$ & Min-Max & & \\
\hline \multicolumn{9}{|l|}{ 8th grade } \\
\hline Problem Solving & 36 & $18.27(7.05)$ & $0-34$ & $-58.49 * *$ & $25.89(9.96)$ & $0-52$ & $-23.63 * *$ & $-17.79 * *$ \\
\hline Motivation & 18 & $16.92(4.74)$ & $6-30$ & $-5.32 * *$ & $15.85(5.19)$ & $6-30$ & $-9.64 * *$ & $4.78 * *$ \\
\hline Self-confidence & 18 & $19.77(3.71)$ & $6-30$ & $11.08 * *$ & $20.79(3.80)$ & $9-30$ & $17.06^{* *}$ & $-5.40 * *$ \\
\hline Familiarity & 18 & $15.69(4.41)$ & $6-30$ & $-12.19 * *$ & $15.20(4.52)$ & $6-30$ & $-14.37 * *$ & $4.21^{*}$ \\
\hline \multicolumn{9}{|l|}{ 10th grade } \\
\hline Problem Solving & 36 & $14.48(7.59)$ & $0-36$ & $-48.70 * *$ & $26.26(9.34)$ & $0-50$ & $-17.90 * *$ & -21.13 \\
\hline Motivation & 18 & $16.23(4.20)$ & $6-29$ & $-7.24 * *$ & $15.99(4.17)$ & $6-30$ & $-8.26^{* *}$ & $1.09(0.276)$ \\
\hline Self-confidence & 18 & $19.35(3.62)$ & $6-29$ & $6.42 * *$ & $20.34(3.32)$ & $10-30$ & $12.11 * *$ & $-1.04(0.299)$ \\
\hline Familiarity & 18 & $16.19(4.05)$ & $6-29$ & $-7.68 * *$ & $16.47(4.23)$ & $6-30$ & $-6.23 * *$ & -4.46 \\
\hline \multicolumn{9}{|l|}{ 11th grade } \\
\hline Problem Solving & 36 & $16.56(8.04)$ & $0-35$ & $-38.80 * *$ & $23.56(9.68)$ & $0-47$ & $-20.65 * *$ & $-12.74 *$ \\
\hline Motivation & 18 & $15.67(4.20)$ & $6-29$ & $-8.89 * *$ & $14.76(4.56)$ & $6-30$ & $-11.41 * *$ & $3.35^{*}$ \\
\hline Self-confidence & 18 & $19.31(3.39)$ & $7-30$ & $6.23 * *$ & $20.35(3.65)$ & $6-30$ & $10.37 * *$ & $-4.33 * *$ \\
\hline Familiarity & 18 & $15.74(3.94)$ & $6-27$ & $-9.22 * *$ & $15.59(4.27)$ & $6-30$ & $-9.08 * *$ & 0.583 \\
\hline
\end{tabular}

Note. 8th grade: $n=542 ; 10$ th grade: $n=295 ; 11$ th grade: $n=258$. T1 = first assessment moment; T2 = second assessment moment. ${ }^{*} p<.05 .{ }^{* *} p<.01 .{ }^{* * *} p<.001$. 
Self-confidence $(M=20.79 ; S D=3.80)$. The differences between the participants' average scores on each index and the respective mean scores are statistically significant for all indices considered. The comparison between the results these participants obtained between $\mathrm{T} 1$ and $\mathrm{T} 2$ indicates the existence of statistically significant differences between the two assessment moments for all indices.

At T1, participants from the 10th grade present results above the mean score on Self-confidence $(M=19.35$; $S D=3.63)$. The analysis of differences between the participants' average results on each index and the respective mean scores indicated statistically significant results for all indices considered. At T2, the recorded results were above the mean score on Self-confidence $(M=20.34$; $S D=3.32$ ). The differences between the participants' average scores for each index and the respective mean scores are statistically significant for all indices considered. The comparison between $\mathrm{T} 1$ and $\mathrm{T} 2$, indicates the existence of statistically significant differences in Problem Resolution $(t(295)=-21.13, p=.000)$ and Familiarity indices $(t(295)=-4.46, p=.000)$.

At T1, participants from the 11th grade present results above the mean score on Self-confidence $(M=19.31$; $S D=3.39$ ). It is important to note that the differences between the average results the participants obtained for each index and the respective mean scores are statistically significant for all indices considered. For T2, results above the mean score were registered on Self-confidence $(M=20,35 ; S D=3.65)$. The comparison between these participants' results between $\mathrm{T} 1$ and $\mathrm{T} 2$ indicates the existence of statistically significant differences between the two assessment moments for several indices, except for Familiarity $(t(257)=.583, p=.560)$.

Table 2 presents the analysis of intergroup differences considering social intelligence levels, comparing students from the 8th, 10th and 11th grades at T1 and T2, using the results of each group at $\mathrm{T} 1$ as covariate.
Considering the $\mathrm{T} 1$, it appears that, on average, participants from the 8th grade had average results superior to the other academic years on Problem Resolution $(M=18.27 ; S D=7.05)$, Motivation $(M=16.92 ; S D=4.74)$ and Self-Confidence $(M=19.77 ; S D=3.71)$, and the 10th grade had average results superior to the remaining academic years for Familiarity $(M=16.19 ; S D=4.05)$. Statistically significant differences between groups were registered in the Problem Resolution index $(F(2,1094)=25.10$, $p=.000$ ) between the 8 th and the 10th grades (Mean difference $=3.80 ; p=.000$ ), the 8 th and the 11 th grades (Mean difference $=1.72 ; p=.010$ ), and the 10th and 11th grades (Mean difference $=-2.08, p=.005$ ), and also in the Motivation index $(F(2,1094)=7.17 ; p=.001)$ between the 8 th and the 11th grades (Mean difference $=1.24 ; p=.001$ ).

Considering T2, and using the results of $\mathrm{T} 1$ as a covariate for each year, statistically significant differences between groups were registered in Problem Resolution $(F(2,1091)=12.77 ; p=.000)$, between the 8th and 10th grades (Mean difference $=-2.36 ; p=.001$ ), and the 10th and 11 th grades (Mean difference $=3.79 ; p=.000$ ), Motivation $(F(2,1091)=3.51 ; p=.030)$, between the 10th and 11th grades (Mean difference $=0.510 ; p=.026$ ), and Familiarity $(F(2,1091)=6.45 ; p=.002)$ and between the 8th and 10th grades (Mean difference $=-1.06 ; p=.001$ ).

\section{Discussion}

The obtained results indicate that students in the 8th, 10th, and 11th grades had significantly lower results that the respective mean scores ion virtually all indexes considered. Therefore, these participants, regardless of the academic grade they are attending, perceived themselves as having weak capacities and strategies to identify and solve social problems (Problem Resolution), as having low interest and pleasure in solving unstructured social problems (Motivation), and as having a weak belief in their ability

Table 2

Social Intelligence Levels in 8th, 10th and 11th Grade Students: Intergroup Differences

\begin{tabular}{|c|c|c|c|c|c|c|}
\hline Fator & Index & Grade & $\begin{array}{c}\mathrm{T} 1 \\
M(S D) \\
\end{array}$ & $\begin{array}{c}\text { ANOVA } \\
F(2,1094) \\
\end{array}$ & $\begin{array}{c}\mathrm{T} 2 \\
M(S D) \\
\end{array}$ & $\begin{array}{l}\text { MANOVA } \\
F(2,1091) \\
\end{array}$ \\
\hline \multirow[t]{12}{*}{ Global } & Problem Solving & 8 th & $18.27(7.05)$ & $25.10 * * *$ & $25.89(9.96)$ & $12.77 * * *$ \\
\hline & & 10th & $14.48(7.59)$ & & $26.26(9.34)$ & \\
\hline & & 11 th & $16.56(8.04)$ & & $23.56(9.68)$ & \\
\hline & Motivation & 8 th & $16.92(4.74)$ & $7.17 * * *$ & $15.85(5.19)$ & $3.51 *$ \\
\hline & & 10th & $16.23(4.20)$ & & $15.99(4.17)$ & \\
\hline & & 11th & $15.67(4.20)$ & & $14.76(4.56)$ & \\
\hline & Self-confidence & 8 th & $19.77(3.71)$ & $1.98(.139)$ & $20.79(3.80)$ & $0.942(.390)$ \\
\hline & & 10th & $19.35(3.62)$ & & $20.34(3.32)$ & \\
\hline & & 11 th & $19.31(3.39)$ & & $20.35(3.65)$ & \\
\hline & Familiarity & 8 th & $15.69(4.41)$ & $1.46(.234)$ & $15.20(4.52)$ & $6.45 * *$ \\
\hline & & 10th & $16.19(4.05)$ & & $16.47(4.23)$ & \\
\hline & & 11th & $15.74(3.94)$ & & $15.59(4.27)$ & \\
\hline
\end{tabular}

${ }^{*} p<.05 . * * p<.01 . * * * p<.001$. 
and skills (Self-confidence) to obtain promising levels of performance and success in different social environments (Greenspan \& Driscoll, 1997; Shure \& Glaser, 2001).

In contrast, these students consider that they know well and have already experienced social situations like those that arise in stimulus-situations of the PCIS (Familiarity), which indicates that participants demonstrate sensitivity to relational constructs (Gouveia, 2008). These results are consistent with those obtained by Pinto, Taveira and Faria (2014), but contradict those obtained by Carvalho (2011) and Pinto, Taveira, Candeias, Carvalho and Marques (2013) who, using samples from the 8th grade, found no statistically significant differences between the participants' results on each index and social situation and the respective normative values. It is important, however, that for these two studies, samples of smaller size and geographical scope have been used, which can be the source of inconsistencies registered against the results of the current study.

In terms of differences between $\mathrm{T} 1$ and $\mathrm{T} 2$, for each year, there is an increase in their perception of Problem Resolution and Self-confidence in all situations, which means that these students believe they have the skills required to identify, develop and put into practice an action plan, and to effectively solve the social problems they face in different contexts (Candeias, Almeida, Roazzi, \& Primi, 2008). However, while the 8th grade students show a decrease in their attitudes of interest to deal with any social situation (Motivation), as well as in the knowledge and previous skills to deal with them (Familiarity), the 11th grade students present a decrease in the first (Motivation), and the 10th grade students show an increase in the second (Familiarity).

Therefore, only the 11th grade seems to have registered, in this period of time, a positive development in terms of their ability to act in a flexible, effective and purposeful way, in the everyday problems that arise in different and changing contexts (Candeias et al., 2008). Considering hypothesis 1 about the existence of statistically significant differences between the averages calculated at the two assessment moments (T1 and T2) in the different grade levels, towards its increase over time, we ascertain that this hypothesis is only partially confirmed. These results can be understood in two ways. On the one hand, younger students may have a more developed academic curriculum from the point of view of the approach of emotional social issues and, therefore, may be more developed in the dimensions assessed, and the results obtained in other studies seem to indicate that this construct is sensitive to development contexts. On the other hand, these 8th grade students may also be presenting themselves in a more positive but less realistic way, because they have also less developed their self-analysis skills.

The comparison between the three academic grades at the first assessment moment indicated the existence of differences in Problem Resolution and Motivation, with superior results for the 8 th grade, meaning that younger students consider themselves to be more motivated and in possession of more capabilities and strategies to identify and solves social problems, compared to older students. Nevertheless, there weren't any differences in Self-confidence and Familiarity, which means a similar perception among younger and older students in respect to their possession of knowledge and competence to deal with the different social situations (Self-confidence and Familiarity). These results contradict those obtained by Candeias (2007) in the standardization sample, according to which the Familiarity with social situations tend to increase with age and Problem Resolution tends to increase as there is an increase not only in age, but in the education of students. Moreover, these results were not congruent either with those previously obtained in the study by Carvalho (2011) and Pinto et al. (2013) which, while placing the focus on the analysis of age and not on education levels, found that younger students (aged under 13) had higher levels of Familiarity with social situations, while older students (aged under 14 years) had higher levels of Self-confidence, not registering differences between groups in the Problem Resolution and Motivation indices.

The comparison between the three academic grades at the second assessment moment and the results of the 1st assessment moment as covariate indicated the existence of differences in Problem Resolution, Motivation and Familiarity, with superior results mainly for the 10th grade, in all of the social situations presented. These results indicate that these students have higher levels of knowledge, skills and strategies related to the resolution of social problems, which is a good predictor of effective social behavior, as well as of their involvement, concern and interest in situations that favor the achievement of personal and socially relevant goals (Birknerová et al, 2013;. Ford, 1995; Joseph \& Lakshmi, 2010). These results contradict the findings in the study by Peixoto (2013), who found that the social problem-solving ability is higher in older students and with higher education. It should also be noted that Self-confidence generates more similarities between the three academic years, which means an approximate perception among students of different ages with respect to their beliefs in how they detain the necessary skills and competencies to address them. Considering hypothesis 2 , which established the existence of statistically significant differences between the averages calculated at the different academic levels, towards better results for students in the 11th grade at both assessment moments (T1 and T2), it appears that the results do not support this prediction.

In sum, these results seem to indicate that the level of social maturity of this Portuguese sample is low relative to expectations, that is, the ways to understand and act in the social world still are not based on the reflective thought necessary to justify an assessment or decision on a problem (Gibbs \& Widaman, 1982, as cited by Candeias et al., 2008). In addition, there are differences between the academic grades with respect to Problem Resolution and Motivation, 
Pinto, J. C., Faria, L., Gaspar, N., \& Taveira, M. C. (2015). Social Intelligence of Portuguese Students.

with students from the 8 th grade obtaining better results. In any case, these results clearly indicate that it is possible to start the promotion of ethical questioning in the 8th grade, as students are motivated and confident with regard to the social and interpersonal dimensions of their development, and may already be sensitive to think about the interpersonal and social implications of their forthcoming decisions. On the other hand, it is important to develop social intelligence in later years, so as to increase the likelihood of the interventions being successful. The levels of social intelligence of the students are directly related to the social learning that the school, the living environment and the socioeconomic status provide (Candeias, 2007). Therefore, young people should be provided opportunities to be involved in activities and experiences for more interaction, participation and social reflection, and therefore more autonomy, interest, and knowledge about social situations.

It should be noted that the study design was conditioned by some limitations that affect its subsequent generalization. Thus, the results should be read in the context of a limited size and heterogeneity of the sample with respect to age, academic years, and place of origin as well. In addition, the implementation of a single assessment instrument should be taken into account, without an external criterion for assessing the validity. In future studies, the various levels of access to social intelligence will need to be considered, ranging from questionnaires to new technologies, or opinions of significant others, in devising a more reliable assessment of the multifaceted and dynamic nature of social intelligence.

The social intelligence seems to pave the way for social reform and social activities that seek to improve human well-being, strengthen civic culture and increase team spirit and commitment to each other, thus contributing to a positive change in society (Joseph \& Lakshmi, 2010). Like several other studies (Boyatzis, 2008; Ciarrochi \& Mayer, 2007; Crowne, 2009; Fletcher et al, 2009; Suliman, 2010), our findings highlight the existence of cognitive and attitudinal conditions favorable to the training of social intelligence, with a possible key role for vocational psychology. As shown in the literature, social intelligence is an independent construct that affects the adjustment and academic achievement of the students and can be facilitated by more general cognitive processes, varying according to the experience and sociodemographic conditions. Moreover, social intelligence and social competence are related, but may be associated with different results and their development may involve different conditions and interventions in educational contexts. Thus, the deepening of the study of social intelligence may be useful for the quality of vocational interventions, to the extent that the vocational intervention process intends to help the client to know his/herself, to position his/herself in the world, to attribute a sense to his/her life projects and to acquire a set of interrelated capabilities with the structure of self-management, social awareness, relationship management and leadership (Taveira, 2000).

\section{References}

Aminpoor, H. (2013). Relationship between social intelligence and happiness in Payame Noor University students. Annals of Biological Research, 4(5), 165-168.

Bartone, P. T., Eid, J., Johnsen, B. H., Laberg, J. C., \& Snook, S. A. (2009). Big five personality factors, hardiness, and social judgment as predictors of leader performance. Leadership \& Organization Development Journal, 30(6), 498-521. doi:10.1108/01437730910981908

Birknerová, Z., Frankovský, M., \& Zbihlejová, L. (2013). Social intelligence in the context of personality traits of teachers. American International Journal of Contemporary Research, 3(7), 11-17.

Bjorkqvist, K. (2007). Empathy, social intelligence and aggression in adolescent boys and girls. In T. F. D. Farrow \& P. W. R. Woodruff (Eds.), Empathy in mental illness (pp. 76-88). New York, NY: Cambridge University Press.

Boyatzis, R. E. (2008). Competencies in the 21 st century. Journal of Management Development, 27(1), 5-12. doi:10.1108/02621710810840730

Boyatzis, R. E., \& Ratti, F. (2009). Emotional, social and cognitive intelligence competencies distinguishing effective Italian managers and leaders in a private company and cooperatives. Journal of Management Development, 28(9), 821-838. doi:10.1108/02621710910987674

Brislin, R., Worthley, R., \& Macnab, B. (2006). Cultural intelligence: Understanding behaviors that serve people's goals. Group \& Organization Management, 31(1), 40-55. doi:10.1177/1059601105275262

Candeias, A. (2003). Prova cognitiva de inteligência social. [Cognitive Test of Social Intelligence]. In M. Gonçalves, M. Simões, L. Almeida, \& C. Machado (Eds.), Avaliação psicológica: Instrumentos validados para a população portuguesa [Psychological assessment: validated instruments for the Portuguese population] (pp. 179-196). Coimbra, Portugal: Quarteto.

Candeias, A. (2007). Prova cognitiva de inteligência social [Cognitive Test of Social Intelligence]. Lisbon, Portugal: CEGOC.

Candeias, A., Almeida, L. S., Roazzi, A., \& Primi, R. (2008). Inteligência: Definição e medida na confluência de múltiplas concepções. [Intelligence: Definition and measure at the confluence of multiple conceptions]. São Paulo, SP: Psychologist House.

Carvalho, V. (2011). Inteligência social em alunos do $8^{\circ}$ ano: Implicações para o questionamento ético dos projetos de vida [Social intelligence in 8th grade students: Implications for the ethical questioning of life projects] (Master's thesis). Retrieved from http://hdl.handle. net/1822/13459

Ciarrochi, J., \& Mayer, J. D. (2007). Applying emotional intelligence: A practitioner's guide. New York, NY: Psychology Press. 
Crowne, K. A. (2009). The relationships among social intelligence, emotional intelligence and cultural intelligence. Organization Management Journal, 6(3), 148-163. doi:10.1057/omj.2009.20

Cherniss, C. (2010). Emotional intelligence: Toward clarification of a concept. Industrial and Organizational Psychology: Perspectives on Science and Practice, 3(2), 110-126. doi:10.1111/j.1754-9434.2010.01231.x

Fletcher, I., Leadbetter, P., Curran, A., \& O’Sullivan, H. (2009). A pilot study assessing emotional intelligence training and communication skills with 3rd year medical students. Patient Education and Counseling, 76(3), 376-379. doi:10.1016/j.pec.2009.07.019

Ford, M. E. (1995). Intelligence and personality in social behavior. In D. H. Saklofske \& M. Zeidner (Eds.), International handbook of personality and intelligence (pp. 125-140). New York, NY: Plenum.

Goleman, D. (2006). Social intelligence: The new science of human relationships. New York, NY: Bantam Books.

Goleman, D., Boyatzis, R., \& McKee, A. (2013). Primal leadership: Unleashing the power of emotional intelligence. Boston, MA: Harvard Business Review Press.

Gouveia, T. L. C. (2008). Vivências escolares e envolvimento parental: Implicações nas atitudes face à escola e no sucesso académico de alunos do ensino secundário [School experiences and parental involvement: Implications for attitudes towards school and academic success of secondary school students] (Master's thesis). Retrieved from http://hdl.handle.net/10216/23734

Greenspan, S., \& Driscoll, J. (1997). The role of intelligence in a broad model of personal competence. In D. P. Flanagan, J. Genshaft, \& P. L. Harrison (Eds.), Contemporary intellectual assessment: Theories, tests, and issues (pp. 131-150). New York, NY: Guilford.

Guilford, J. P. (1967). The nature of human intelligence. New York, NY: McGraw-Hill.

Joseph, C., \& Lakshmi, S. S. (2010). Social intelligence, a key to success. The IUP Journal of Soft Skills, 4(3), 15-21.

Juchniewicz, J. (2010). The influence of social intelligence on effective music teaching. Journal of Research in Music Education, 58(3), 276-293. doi:10.1177/0022429410378368

Koydemir, S., Simsek, O. F., Schutz, A., \& Tipandjan, A. (2013). Differences in how trait emotional intelligence predicts life satisfaction: The role of affect balance versus social support in India and Germany. Journal of Happiness Studies, 14(1), 51-66. doi:10.1007/s10902-011-9315-1

Lacanlale, E. (2013). Development and validation of a social intelligence inventory. International Journal of Information and Education Technology, 3(2), 263-267. doi:10.7763/IJIET.2013.V3.277

Lopez, V. (2007). Social intelligence: Contributions from its study in children and adolescents with high cognitive abilities. Psykhe, 16(2), 17-28. doi:10.4067/S0718-22282007000200002
Meijs, N., Cillessen, A. H. N., Scholte, R. H. J., Segers, E., \& Spijkerman, R. (2010). Social intelligence and academic achievement as predictors of adolescent popularity. Journal of Youth and Adolescence, 39(1), 62-72. doi:10.1007/s10964-008-9373-9

Moss, F. A., \& Hunt, T. (1927). Are you socially intelligent? An analysis of the score of 7000 persons on the George Washington University social intelligence test. Scientific American, 137(2), 108-111.

Nagra, V. (2014). Social intelligence and adjustment of secondary school students. Paripex - Indian Journal of Research, 3(4), 86-87.

Peixoto, M. E. (2013). Inteligência emocional e competência social em alunos do ensino secundário [Emotional inteligence and social competence in secondary education students] (Unpublished master's thesis). Universidade do Minho, Braga, Portugal.

Pinto, J. C., Faria, L., \& Taveira, M. C. (2014). Social intelligence in Portuguese students: Differences according to the school grade. Procedia - Social and Behavioral Sciences, 116, 56-62. doi:10.1016/j.sbspro.2014.01.168

Pinto, J. C., Taveira, M. C., Candeias, A., Carvalho, V., \& Marques, C. (2013). Social intelligence in 8th grade students: Differences according to sex and age. Proceedings of the International Conference on Education and New Learning Technologies, 4, 4752-4759.

Por, J., Barriball, L., Fitzpatrick, J., \& Roberts, J. (2011). Emotional intelligence: Its relationship to stress, coping, well-being and professional performance in nursing students. Nurse Education Today, 31(8), 855-860. doi:10.1016/j.nedt.2010.12.023

Pretz, J. E., Naples, A. J., \& Sternberg, R. J. (2003). Recognizing, defining and representing problems. In J. E. Davidson \& R. J. Sternberg (Eds.), The psychology of problem solving (pp. 3-30). New York, NY: Cambridge University Press.

Saxena, S., \& Jain, R. K. (2013). Social intelligence of undergraduate students in relation to their gender and subject stream. Journal of Research \& Method in Education, 1(1), 1-4.

Shure, M. B., \& Glaser, A. L. (2001). I can problem solve (ICPS): A cognitive approach to the prevention of early high-risk behaviors. In J. Cohen (Ed.), Caring classrooms/intelligent schools: The social emotional education of young children (pp. 122-139). New York, NY: Teachers College Press.

Soares, A. B., Francischetto, V., Peçanha, A. P. C. L., Miranda, J. M., \& Dutra, B. M. S. (2013). Intelligence and social competence in university adaptation. Estudos de Psicologia (Campinas), 30(3), 317-328. doi:10.1590/S0103-166X2013000300001

Song, L. J., Huang, G.-H., Peng, K. Z., Law, K. S., Wong, C.-S., \& Chen, Z. (2010). The differential effects of general mental ability and emotional intelligence on academic performance and social interactions. Intelligence, 38(1), 137-143. doi:10.1016/j.intell.2009.09.003 
Suliman, W. A. (2010). The relationship between learning styles, emotional social intelligence, and academic success of undergraduate nursing students. Journal of Nursing Research, 18(2), 136-143. doi:10.1097/JNR.0b013e3181dda797

Taveira, M. C. (2000). Exploração e desenvolvimento vocacional de jovens: Estudo sobre as relações entre a exploração, a identidade e a indecisão vocacional [Vocational exploration and development in adolescents: A study about the relationships between vocational exploration, identity and indecision] (Unpublished doctoral dissertation). Universidade do Minho, Braga, Portugal.

Thorndike, E. L. (1920). Intelligence and its uses. Harper's Monthly Magazine, 140, 227-235.

Vernon, P. E. (1933). Some characteristics of the good judge of personality. Journal of Social Psychology, 4(1), 42-57. doi:10.1080/00224545.1933.9921556

Wechsler, D. (1958). The measurement and appraisal of adult intelligence (4th ed.). Baltimore, MD: Williams \& Wilkins.

Yahyazadeh-Jeloudar, S., \& Lotfi-Goodarzi, F. (2012). The relationship between social intelligence and job satisfaction among MA and BA teachers. International Journal of Educational Science, 4(3), 209-213.

Zirkel, S. (2000). Social intelligence: The development and maintenance of purposive behavior. In R. Bar-On \& J. D. A. Parker (Eds.), The handbook of emotional intelligence: Theory, development, assessment, and application at home, school and in the workplace (pp. 3-27). San Francisco, CA: Jossey-Bass.

Joana Carneiro Pinto is a Professor at the School of Human Sciences of Universidade Católica Portuguesa.

Liliana Faria is a Professor of Universidade Europeia.

Neide Gaspar is a M.S. in Social and Organizational Psychology from Instituto Superior de Línguas e Administração de Leiria.

Maria do Céu Taveira is a Professor of Universidade do Minho.

Received: July 1, 2014

1st Revision: Nov. 4, 2014

2nd Revision: Jan. 23, 2015

Approved: Jan. 27, 2015

How to cite this article:

Pinto, J. C., Faria, L., Gaspar, N., \& Taveira, M. C. (2015). Intra and inter-individual differences in social intelligence of Portuguese students. Paidéia (Ribeirão Preto), 25(61), 153-161. doi:10.1590/1982-43272561201503 